\title{
OPEN Author Correction: Next Generation Sequencing of Pooled Samples: Guideline for Variants' Filtering
}

\section{Santosh Anand, Eleonora Mangano, Nadia Barizzone, Roberta Bordoni, Melissa Sorosina, Ferdinando Clarelli, Lucia Corrado, Filippo Martinelli Boneschi, Sandra D’Alfonso \& Gianluca De Bellis}

Correction to: Scientific Reports https://doi.org/10.1038/srep33735, published online 27 September 2016

This Article contains an expired email address for Santosh Anand. Correspondence and requests for materials should be addressed to santosh.anand@gmail.com.

\begin{abstract}
Open Access This article is licensed under a Creative Commons Attribution 4.0 International License, which permits use, sharing, adaptation, distribution and reproduction in any medium or format, as long as you give appropriate credit to the original author(s) and the source, provide a link to the Creative Commons license, and indicate if changes were made. The images or other third party material in this article are included in the article's Creative Commons license, unless indicated otherwise in a credit line to the material. If material is not included in the article's Creative Commons license and your intended use is not permitted by statutory regulation or exceeds the permitted use, you will need to obtain permission directly from the copyright holder. To view a copy of this license, visit http://creativecommons.org/licenses/by/4.0/.
\end{abstract}

(C) The Author(s) 2020 